\title{
A BACKWARD LOOKING MEASURE OF THE EFFECTIVE MARGINAL TAX BURDEN ON INVESTMENT
}

\author{
JOHANNES BECKER
}

CLEMENS FUEST

\author{
CESIFO WORKING PAPER NO. 1342 \\ CATEGORY 1: Public FinANCE \\ NOVEMBER 2004
}

- from the CESifo website: $\quad$ www.CESifo.de 


\title{
A BACKWARD LOOKING MEASURE OF THE EFFECTIVE MARGINAL TAX BURDEN ON INVESTMENT
}

\begin{abstract}
Forward looking measures like the well-known effective marginal tax rate developed by King and Fullerton (1984) are often criticized for not taking into account the complexity of the tax law. This paper derives a method of evaluating this kind of measure and of quantifying the bias resulting from simplifying assumptions, especially on the pattern of depreciation deductions. We apply our method to German data and find that even small estimation biases in determining the tax deductions have a large impact on the effective tax rates for marginal and inframarginal investment projects. We conclude that our method may be used to quantify exactly the difference between the actual use of depreciation deductions and the KingFullerton assumptions and therefore to correct the conventional forward looking measures.
\end{abstract}

JEL Code: H21, H25.

Keywords: effective tax rates, corporate taxation.

Johannes Becker

Seminar für Finanzwissenschaft

University of Cologne

Albertus-Magnus-Platz

50923 Cologne

Germany

johannes.becker@uni-koeln.de
Clemens Fuest

Seminar für Finanzwissenschaft

University of Cologne

Albertus-Magnus-Platz

50923 Cologne

Germany

clemens.fuest@uni-koeln.de

We thank the IW Consult GmbH for data support. 


\section{Introduction}

In recent years, many countries have implemented tax reforms designed to stimulate investment and growth. Given this objective, it is important to assess the impact of these reforms on the effective tax burden on investment. Measuring the tax burden on investment, however, is a difficult task. In the literature, the dominating concept is the effective marginal tax rate measure introduced by King \& Fullerton (1984). The KF effective marginal tax rate is a forward looking concept. On the basis of statutory tax rates and tax bases, KF (1984) consider a permanent increase in the capital stock of a representative firm and calculate the tax burden on the basis of the difference between the rate of return of the marginal investment and the return required by the investor. The KF approach allows to calculate the marginal tax burden on investment in different types of assets and under different assumptions on the source of financing. As every forward looking concept, the KF approach has the disadvantage that it does not use the actual behaviour of economic agents in order to assess the tax burden on investment. ${ }^{1}$

Recently, Gordon, Kalambokidis \& Slemrod (2003) have suggested a new measure of the marginal tax burden on investment. The difference to KF (1984) is that this new measure is a backward looking concept. Under certain assumptions it can be shown that the depreciation deductions in one period can be used to approximate the future deductions of the investment project under consideration. However, due to its strict assumptions this new measure has several shortcomings when applied to real world data.

The purpose of the analysis in this paper is twofold. Firstly, we reconsider and refine the main idea of the GKS approach and we explore the consequences of relaxing some of the assumptions made in GKS (2003). On the basis of this idea, we develop a method of evaluating the KF-style measures and correcting them for errors due to tax law complexities. The second purpose of this paper is to apply our method to German balance sheet data. The results of our empirical analysis suggest that forward looking measures slightly overestimate the average effective marginal tax burden on investment. The reason is that the assumed tax depreciation rules are more restrictive than the tax depreciation actually observed in the data. Moreover, the accuracy of forward looking indicators varies considerably across firms. We investigate the factors explaining the differences across firms and find that tax depreciation is unexpectedly high in firms with a low share of fixed assets and low levels of debt financing.

Apart from serving as an empirical check on the accuracy of forward looking indicators of the effective tax burden, our methodology and our empirical results may also be seen as a first step towards reconciling the results of studies based on forward looking measures of the effective tax burden with those based on backward looking measures, who usually find lower

\footnotetext{
${ }^{1}$ Devereux \& Griffith (1998) develop a variant of the KF approach that allows to compute effective marginal and average tax rates in a common theoretical framework. Another well known forward looking concept is the European Tax Analyzer developed by Jacobs \& Spengel (1996). Their approach is based on a model firm and allows to derive effective average tax rates.
} 
effective tax rates.

The setup of the paper is as follows. In the next section, we consider a standard model of investment and describe the theoretical basis of the empirical approach we use. In section 3, we apply our method to German data and compute the adjusted effective tax rates. Section 4 concludes.

\section{The model}

\subsection{The capital cost approach}

We consider a standard model of an infinitely lived firm. At the beginning of period $t$, the firm invests $I_{t}$ in non-financial assets. The firm's capital stock in period $t$ is $K_{t}$, where

$$
K_{t}=(1-\delta) K_{t-1}+I_{t}
$$

is the capital stock resulting from investment in the current and earlier periods. $I_{t}$ is the amount of gross investment in period $t$ and $\delta$ is the rate of economic depreciation. Investment is either financed by debt or retained earnings. The share of debt financing is denoted by $b$. Following King \& Fullerton (1984), we assume that the firm considers a permanent increase in the capital stock. This implies that an investment $I_{t}$ in period $t$ triggers an additional replacement investment of $\delta I_{t}$ in each subsequent period. Given this, the firm's market value $V_{t}$ of the project under consideration can be written as

$$
V_{t}^{*}=-I_{t}(1-b)-\sum_{s=1}^{\infty} \frac{i b I_{t}}{(1+i)^{s}}+\sum_{s=1}^{\infty} \frac{(1+\pi)^{s}\left[F_{t+s}\left(K_{t}\right)-F_{t+s}\left(K_{t}-I_{t}\right)-\delta I_{t}\right]}{(1+i)^{s}}
$$

where $i$ is the nominal interest rate and $\pi$ is the rate of inflation. Henceforth, the "*" stands for the absence of taxes. We assume that inflation in output prices equals inflation in prices for investment goods. With $f_{t}=\frac{F_{t}\left(K_{t}\right)-F_{t}\left(K_{t}-I_{t}\right)}{I_{t}}$ the output surplus per unit of investment and $v_{t}=\frac{V_{t}}{I_{t}}$, it follows:

$$
v_{t}^{*}=-1+\sum_{s=1}^{\infty}\left(\frac{1+\pi}{1+i}\right)^{s}\left(f_{t+s}-\delta\right)
$$

With $f_{t+s}=f$, for every $s$, the project value becomes:

$$
v_{t}^{*}=-1+(f-\delta) \frac{1+\pi}{i-\pi}
$$

What is the impact of introducing taxes? We focus on taxes at the firm level and abstract from personal taxes. In the presence of taxes, the present value of the firm's cash flow related to the project becomes 


$$
\begin{aligned}
v_{t}= & -(1-b)+u \sum_{s=1}^{\infty} \frac{d_{s}}{(1+i)^{s}}-\delta \sum_{s=1}^{\infty} \frac{(1+\pi)^{s}\left(1-u \sum_{\tau=1}^{\infty} \frac{d_{s}}{(1+i)^{\tau}}\right)}{(1+i)^{s}} \\
& -(1-u) \sum_{s=1}^{\infty} \frac{i b}{(1+i)^{s}}+(1-u) \sum_{s=1}^{\infty}\left(\frac{1+\pi}{1+i}\right)^{s} f_{t+s}
\end{aligned}
$$

where $u$ is the corporate tax rate and $d_{s}$ is the rate of depreciation for $s$ year old investment goods. Note that future replacement investment is assumed to be fully financed through equity and depreciated as any other kind of non-financial investment.

For the marginal investment, the project value (denoted as $v_{t}^{m}$ ) equals zero.

$$
\begin{aligned}
v_{t}^{m}= & -(1-b)+u \sum_{s=1}^{\infty} \frac{d_{s}}{(1+i)^{s}}-\delta \sum_{s=1}^{\infty}\left(\frac{1+\pi}{1+i}\right)^{s}\left(1-u \sum_{\tau=1}^{\infty} \frac{d_{s}}{(1+i)^{\tau}}\right) \\
& -(1-u) \sum_{s=1}^{\infty} \frac{i b}{(1+i)^{s}}+(1-u) \sum_{s=1}^{\infty}\left(\frac{1+\pi}{1+i}\right)^{s} f_{t+s}^{m}=0
\end{aligned}
$$

As above, assume that $f_{t+s}^{m}=f^{m}$, for every $s$, and it follows:

$$
f^{m}-\delta=\frac{i-\pi}{1+\pi}+\frac{u\left[\left(\frac{i-\pi}{1+\pi}+\delta\right)\left(1-\sum_{s=1}^{\infty} \frac{d_{s}}{(1+i)^{s}}\right)-\frac{i-\pi}{1+\pi} b\right]}{1-u}
$$

The right hand of (7) represents the cost of capital for the marginal investment. The first term is equal to the cost of capital in the absence of taxes and the second term is the "tax wedge". Note that, in the case of immediate depreciation $\left(\sum_{s=1}^{\infty} \frac{d_{s}}{(1+i)^{s}}=1\right)$ and with full equity financing (or no deductibility of interest on debt), the tax wedge on the marginal investment disappears, as one would expect. The effective marginal tax rate $(E M T R)$ is given by $E M T R=\frac{f^{m}-\delta-\frac{i-\pi}{1+\pi}}{f^{m}-\delta}$, or:

$$
E M T R=\frac{u\left[1-\sum_{s=1}^{\infty} \frac{d_{s}}{(1+i)^{s}}-r b\right]}{(1-u) r+u\left[1-\sum_{s=1}^{\infty} \frac{d_{s}}{(1+i)^{s}}-r b\right]}
$$

where

$$
r=\frac{i-\pi}{(i-\pi+(1+\pi) \delta)}
$$

The next step will be to develop methods how to compute the EMTRs. 


\subsection{The King-Fullerton-approach}

Following the standard approach by King and Fullerton (1984) equation (8) can be computed on the basis of legal provisions in the tax law:

$$
\operatorname{EMTR}_{K F}=\frac{u\left[1-\sum_{s=1}^{\infty} \frac{e_{s}}{(1+i)^{s}}-r b\right]}{(1-u) r+u\left[1-\sum_{s=1}^{\infty} \frac{e_{s}}{(1+i)^{s}}-r b\right]}
$$

where the $e_{s}$ denote the legal provisions for depreciation deductions. This forward-looking method has often been criticized for not taking into account the entire complexity of the tax law and the variety of special legal provisions that allow firms to lower their tax burden.

\subsection{The GKS idea}

This criticism is referred to in recent work by Gordon, Kalambokidis and Slemrod (2003), henceforth GKS, who propose an empirically based method of computing the EMTR. Their method approximates $\sum_{s=1}^{\infty} \frac{d_{s}}{(1+i)^{s}}$ on the basis of historical data. Denote as $D_{t}$ the tax depreciation of a firm in period $t$. $D_{t}$ is a result of investment in previous periods and can be written as

$$
D_{t}=\sum_{m=1}^{\infty} d_{m} I_{t-m}
$$

where $d_{m}$ denotes the tax depreciation for $m$ year old capital ${ }^{2}$. Dividing by $I_{t}$ and assuming that investment grows at a constant rate $\omega$ leads to the expression

$$
\frac{D_{t}}{I_{t}}=\sum_{m=1}^{\infty} \frac{d_{m}}{(1+\omega)^{m}}
$$

GKS (2003b) assume that the tax law remains stable, that the investment growth rate $\omega$ equals the nominal interest rate $i$ and that the asset structure is constant. Under these assumptions, the ratio $\frac{D_{t}}{I_{t}}$ equals the present value of depreciation deductions $\sum_{s=1}^{\infty} \frac{d_{s}}{(1+i)^{s}}$ for new investment. Thus, the ratio $\frac{D_{t}}{I_{t}}$ observed in the data can serve as an empirical approximation for future depreciation deductions available for new investment. The EMTR can thus be written as:

$$
\operatorname{EMTR}_{G K S}=\frac{u\left[1-\frac{D_{t}}{I_{t}}-r b\right]}{(1-u) r+u\left[1-\frac{D_{t}}{I_{t}}-r b\right]}
$$

If the tax law remains stable over time and if the assumption $i=\omega$ is satisfied, $E M T R_{G K S}$ can be compared directly to $E M T R_{K F}$ in order to check whether the assumptions made on depreciation allowances $e_{m}$ are empircally correct. ${ }^{3}$ Unfortunately, the tax law changes

\footnotetext{
${ }^{2}$ The time vector $\mathrm{s}$ denotes the future, $\mathrm{m}$ the past.

${ }^{3}$ If there are differences between $E M T R_{G K S}$ and $E M T R_{K F}$, these can only be due to differences in the
} 
frequently and there is no reason why the investment growth rate should be equal to the nominal interest rate. In fact, in our data set, the investment growth rate is much lower than the interest rate. A lognormal regression over the period under consideration (1993-2002) yields a growth rate of $\omega=1,44 \%$ whereas the average bond yield is $i=6,7 \%$. We therefore have to relax the assumptions made in GKS.

\subsection{Relaxing some GKS assumptions}

\subsubsection{Different investment growth}

If $i \neq \omega$ the analysis becomes somewhat more complicated, since $D_{t} / I_{t}$ as an estimator for future depreciation deductions is now biased depending on the difference between $i$ and $\omega{ }^{4}$ We may solve this problem as follows. The "true" depreciation allowances $d_{m}$ of equation (12) can be divided into "regular" deductions $e_{m}$ accounted for in the KF-measure and "special" deductions $g_{m}$ :

$$
\frac{D_{t}}{I_{t}}=\sum_{m=1}^{\infty} \frac{d_{m}}{(1+\omega)^{m}}=\sum_{m=1}^{\infty} \frac{e_{m}}{(1+\omega)^{m}}+\sum_{m=1}^{\infty} \frac{g_{m}}{(1+\omega)^{m}}
$$

Here, we could simply isolate $\sum_{m=1}^{\infty} \frac{g_{m}}{(1+\omega)^{m}}$ in order to compute the impact of "special" deductions. The problem is that our real interest is the present value of special depreciation allowances for future investment, which is discounted at rate $i$ which diverges significantly from $\omega$. We therefore have to assume that special depreciation allowances are a constant share $\kappa$ of the "regular" deduction $e_{m}$, so that (15) can be expressed as:

$$
\frac{D}{I}=\sum_{m=1}^{\infty} \frac{e_{m}}{(1+\omega)^{m}}+\sum_{m=1}^{\infty} \frac{\kappa e_{m}}{(1+\omega)^{m}}=(1+\kappa) \sum_{m=1}^{\infty} \frac{e_{m}}{(1+\omega)^{m}}
$$

The parameter $\kappa$ can be interpreted as a measure of how much observed depreciation allowances deviate from allowances assumed in forward looking effective tax rate measures. $\kappa$ can be estimated by:

$$
\hat{\kappa}=\frac{D / I}{\left(\sum_{m=1}^{\infty} \frac{e_{m}}{(1+\omega)^{m}}\right)}-1
$$

where $\hat{\kappa}$ is the estimator for $\kappa, D$ are the actual deductions taken from our data sample and $\sum_{m=1}^{\infty} \frac{e_{m}}{(1+\omega)^{m}}$ is the modified King-Fullerton deductions term, where the discount factor $i$

depreciation allowances $e_{m}$ and $d_{m}$. This can be seen by considering the difference in the tax wedge $(T W)$ as calculated under the $K F$ approach and the $G K S$ approach. Under the assumption $i=\omega$, this difference is given by

$$
T W^{K F}-T W^{G K S}=\frac{u\left(\frac{i-\pi}{1+\pi}+\delta\right)}{(1-u)}\left[\sum_{m=1}^{\infty} \frac{d_{m}}{(1+i)^{m}}-\sum_{m=1}^{\infty} \frac{e_{m}}{(1+i)^{m}}\right] .
$$

${ }^{4}$ If $i>\omega, D_{t} / I_{t}$ overestimates depreciation allowances (and thus underestimates the effective marginal tax rate) and vice versa. 
has been changed to $\omega$. Given this, we can establish an adjusted effective marginal tax rate.

$$
\operatorname{EMTR}_{a d j}=\frac{u\left[1-(1+\kappa) \sum_{s=1}^{\infty} \frac{e_{s}}{(1+i)^{s}}-r b\right]}{(1-u) r+u\left[1-(1+\kappa) \sum_{s=1}^{\infty} \frac{e_{s}}{(1+i)^{s}}-r b\right]}
$$

In order to calculate this adjusted effective marginal tax rate, two additional complications have to be taken into account: The first is that the tax law may change and the second is that the tax law treats different types of assets differently.

\subsubsection{Changing tax law}

The tax law, especially the provisions for depreciation deductions, is changed quite frequently. This has to be taken into account in our approach. For instance, if the present tax system contains more generous deductions than before, the estimator $\hat{\kappa}$ in equation (17) would be biased downwards. We therefore have to correct for tax policy changes, which can be done by writing our estimator $\hat{\kappa}$ as

$$
\hat{\kappa}=\frac{D / I}{\left(\sum_{m=1}^{\infty} \frac{e_{m}}{(1+\omega)^{s}}+H\right)}-1
$$

where $H=\sum_{m=1}^{\infty} \frac{h_{m}-e_{m}}{(1+\omega)^{s}}$ is a correction term which is computable on the basis of the tax law. The $h_{m}$ correspond to the depreciation rules which were valid in the period when the investment was realized.

\subsubsection{Investment structure}

So far, we have analyzed the problem for a single type of asset. In reality the capital stock is composed of different asset types, each of which is treated differently in the tax law and has a different rate of economic depreciation. We therefore reformulate equation (19):

$$
\hat{\kappa}_{t}=\frac{D_{t}}{\sum_{k=1}^{K} \sum_{m=1}^{M_{k}} h_{m, k} I_{t-m, k}}-1
$$

where $K$ is the number of assets and $M_{k}$ is the number of periods in which the asset $k$ is depreciated. Thus $\sum_{k=1}^{K} \sum_{m=1}^{M_{k}} h_{m, k} I_{t-m, k}$ can be understood as a virtual time path of depreciation deductions. 


\section{Empirical Evidence}

In this section, we apply our method to German data. The basic idea of our approach may be summarized as follows. For the investment observed in the data ${ }^{5}$, we calculate the path of tax depreciations which would arise if the depreciation rules assumed by forward looking measures of the effective tax burden were applied. We then compare this hypothetical path of depreciation to the tax depreciation observed in the data. The difference between the two is summarized in the parameter $\kappa$. We will then use our results on $\kappa$ to assess the current effective tax burden on investment in Germany.

\subsection{The data}

We use data from the DAFNE database which includes balance sheet data of 22.000 German firms from different industrial and commercial branches covering the period from 1993 to 2002. In order to estimate $\kappa$ we need data covering at least eight years without interruption, which corresponds to the depreciation duration of machines ${ }^{6}$. We have to exclude all firms which do not satisfy this condition. After all, 1495 firms remain in our dataset.

Table 1 provides a descriptive statistic of the data sample. The capital stock is measured in thousand Euro. For immaterials, tangible assets and inventories the fractions of the capital stock are given. The difference to 1 is the fraction of financial assets. The average firm has a leverage (= debt through total capital) of $45,5 \%$.

\begin{tabular}{|llll|}
\hline & mean & stand. dev. & median \\
\hline capital stock & 495.956 & 3.755 .774 & 93.700 \\
\hline immaterials & 0,067 & 0,563 & 0,005 \\
\hline tangible assets & 0,413 & 0,303 & 0,363 \\
of which structures & 0,375 & 0,370 & 0,234 \\
of which machines & 0,625 & 0,370 & 0,766 \\
\hline inventories & 0,107 & 0,150 & 0,036 \\
\hline debt ratio & 0,455 & 0,239 & 0,446 \\
\hline
\end{tabular}

Table 1: Descriptive statistics

As explained in section 2, we have to take into account that the tax law has changed in 2001. Table 2 presents the difference between the former and the new deduction system.

\footnotetext{
${ }^{5}$ Since the capital stock in the balance sheet is only decreased by depreciation deductions, $I_{t}$ can be constructed by:

$$
I_{t}=K_{t}-K_{t-1}+D_{t}
$$

The $K_{t}$ and the $D_{t}$ can be drawn from the balance sheet data.

${ }^{6}$ That means, that $M_{k}$ is not higher than 7 for any of the asset types except for structures and buildings. Here, we assume that the whole stock of structures and buildings can be depreciated, i.e. that all buildings have been built in the last 25 years. We therefore might overstate the true depreciation deductions.
} 


\begin{tabular}{|l|l|l|l|l|}
\hline Asset type & \multicolumn{2}{|c|}{$\mathbf{\ldots - 2 0 0 0}\left(h_{k}\right)$} & \multicolumn{2}{c|}{ 2001-... $\left(e_{k}\right)$} \\
\hline & \multicolumn{1}{|c|}{ type } & years & \multicolumn{1}{|c|}{ type } & years \\
\hline Immaterials & linear (20\%) & 5 & linear $(20 \%)$ & 5 \\
Machines & degr. (30\%) & 4 & degr. $(20 \%)$ & 2 \\
& linear (8\%) & 3 & linear $(12,8 \%)$ & 5 \\
Structures & linear (4\%) & 25 & linear (3\%) & 33 \\
Inventories & - & - & - & - \\
\hline
\end{tabular}

Table 2: Deduction rules

\subsection{Results}

\subsubsection{The estimation of $\kappa$}

As pointed out in the theoretical section, we estimate the share of special deductions $\kappa$ by constructing a virtual time path of tax deductions. With 1495 firms in our dataset we compute 3157 estimates of $\kappa$ for the years 2000-2002 using equation (20), 1498 estimates for the year 2000, 982 for 2001 and 681 for 2002. Table 3 presents the most important parameters of the $\kappa$ estimates.

\begin{tabular}{|l|l|}
\hline mean & 0,294 \\
\hline standard deviation & 1,839 \\
\hline median & 0,069 \\
\hline
\end{tabular}

Table 3: estimation results

On average, the observed tax deductions of firms exceed those assumed by forward looking $\mathrm{KF}$ style measures by 30\%. However, the high standard deviation and the smaller median suggest that we should take a closer look at the distribution of $\kappa$.

Figure 1 shows the distribution of $\kappa$ in decile classes. Due to its construction, $\kappa$ can take values between -1 and $+\infty$. The last column at the right side shows the number of $\kappa$ with a value greater than 2,9. At first glance, $\kappa$ seems to have a normally shaped distribution around zero exhibiting a moderate right skewness. 


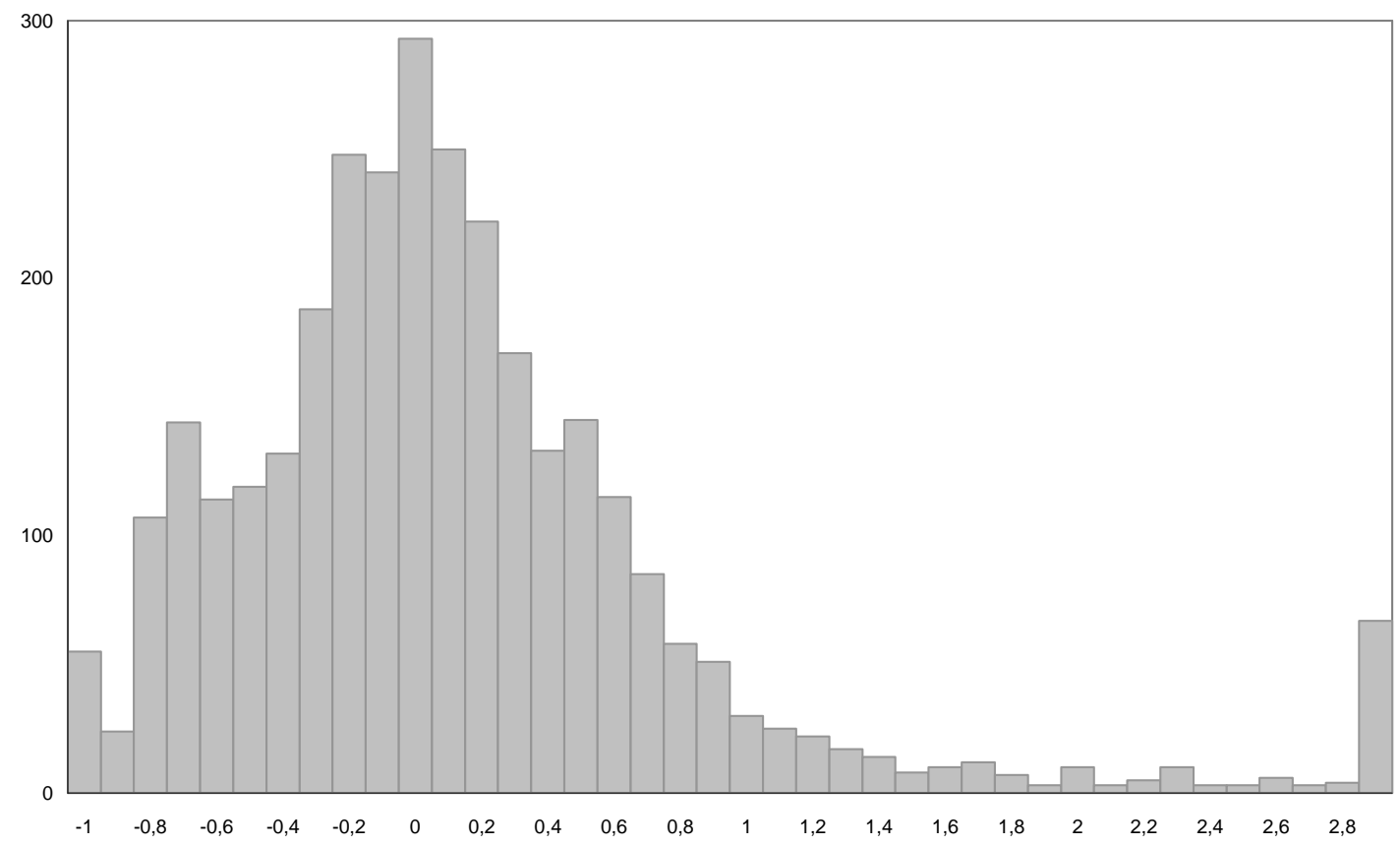

Figure 1: distribution of $\kappa$

Typically, arithmetic means of skewed distributions react strongly to the exclusion of extreme values. Figure 2 shows how the mean develops as a function of the number of extreme values excluded. The mean quickly falls below 0,1 and then gradually converges to the median.

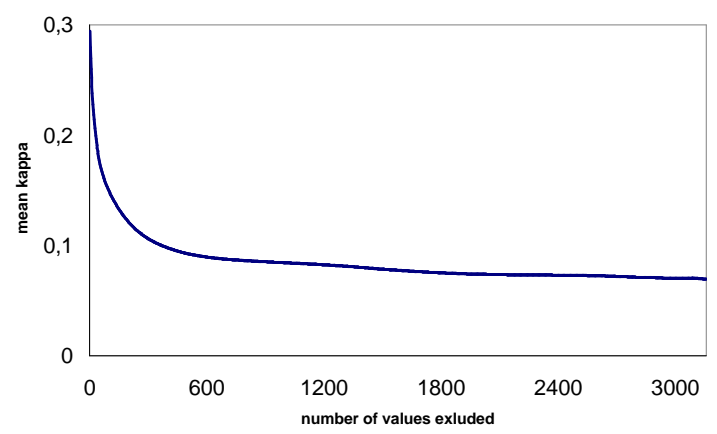

Figure 2: mean and number of excluded values

The average $\kappa$ takes values between 0,294 and 0,069, depending on the number of excluded values. In economic terms, the average firms depreciates between $7 \%$ and $30 \%$ more than suggested by the forward-looking measures. On the basis of these estimates, we are now able to compute an adjusted EMTR.

\subsubsection{The adjusted EMTR}

In the following, the EMTR is computed with and without taking into account the correction parameter $\kappa$. For simplicity, we consider an investment project with an asset structure 
corresponding to the average asset structure in the sample (without inventories and financial assets) ${ }^{7}$, which is presented in Table 4 .

\begin{tabular}{|llll|}
\hline Asset type & Immaterials & Structures & Machines \\
Share & $14,0 \%$ & $32,3 \%$ & $53,7 \%$ \\
\hline
\end{tabular}

Table 4: Asset structure

The statutory tax rate $u$ has been calculated by Spengel (2001) on the basis of statutory rates of the German corporate income tax ("Körperschaftsteuer") and the local business tax ("Gewerbeertragsteuer"). We adopt this value and set $u=39,4 \%$.

The assumptions on the economic depreciation $\delta$ correspond to average depreciation rates used by the German Council of Economic Advisers (Sachverständigenrat (2001)) ${ }^{8}$. Given the structure of our hypothetical investment project, the total rate of economic depreciation is $\delta=6,6 \%$. The values for the nominal interest rate $(i=7 \%)$ and the inflation rate $(\pi=2 \%)$ are adopted as well.

Obviously, the share of debt financing $b$ at the margin may differ from average debt financing. We therefore consider three different values of $b$ : pure equity finance $(b=0)$, pure debt finance $(b=1)$ and mixed finance $(b=44,4 \%)$, which corresponds to the average debt financing share of the whole capital stock in our data set.

Table 5 shows the effective marginal tax rate according to the conventional method $(\kappa=0)$ and with different $\kappa$ ranging between the median $(\kappa=6,9 \%)$ and the arithmetic mean $(29,6 \%)$.

\begin{tabular}{|l|r|r|r|r|r|}
\hline & EMTR (\%) & \multicolumn{4}{|c|}{ adjusted EMTR (\%) } \\
\hline $\mathrm{b}(\%)$ & $\kappa=0 \%$ & $\kappa=6,9 \%$ & $\kappa=10 \%$ & $\kappa=20 \%$ & $\kappa=29,6 \%$ \\
\hline 0 & 34,2 & 31,0 & 29,5 & 24,1 & 18,1 \\
44,4 & 18,7 & 13,9 & 11,5 & 2,8 & $-7,3$ \\
100 & $-15,1$ & $-25,1$ & $-30,2$ & $-49,8$ & $-75,2$ \\
\hline
\end{tabular}

Table 5: EMTR with and without kappa

It becomes clear, that even with a relatively small $\kappa$ of about $7 \%$ the effective marginal tax rate is considerably biased downwards. With a rising $\kappa$ the bias incrases quickly.

\subsection{Explanation of differences in $\kappa$ across firms}

As shown in the preceding section, the distribution of $\kappa$ has a large variance. There seem to be firms which deduct much more than the KF style measures assume and others which apparently "play the rules". This raises the question of what determines the different levels of $\kappa$. Theoretically, there are several factors which might have an impact on depreciation

\footnotetext{
${ }^{7}$ Note that our results do not depend on the specific asset structure of the investment project. However, to illustrate our results we have to assume some structure.

${ }^{8}$ The calculations of the Council of Economic advisers are based on Spengel (2001), where the assumptions on economic depreciation and tax depreciation rates can be found.
} 
behaviour. Firstly, there might be sector specific differences in $\kappa$ because of sector specific depreciation allowances which are not captured by KF assumptions. Secondly, it is likely that firms will try less hard to use special depreciation allowances if they have other tax shields, such as a high level of debt or losses which are carried forward. Finally, it may be that depreciation behaviour depends on the structure of assets or the organizational form. In order to investigate these issues, we have run regressions where we use $\kappa$ as the dependent variable and try to explain its value as a function of (1) the sector, (2) the organizational form and (3) the structure of the balance sheet.

\subsection{1 $\kappa$ and different sectors}

Our data sample contains data points from firms in the following industrial and commercial sectors: agriculture (12 firms), mining (21), manufacturing (825), energy (620), construction (83), commerce (290), restaurants (5), transport (227), banking (24), real estate (813), public administration (8), education (6), health (80) and other public services (87).

Does the value of $\kappa$ depend on the sector for which could exist special depreciation opportunities? Table 6 shows the regression results for $\kappa$ with two time dummies and different branches as independent variables. As in every following regression result the time dummy for 2002 has a significant positive coefficient. This should not be overinterpreted, though, since the number of observations differ in each year. There are two sectors which exhibit highly significant regression values: agriculture and the banking sector.

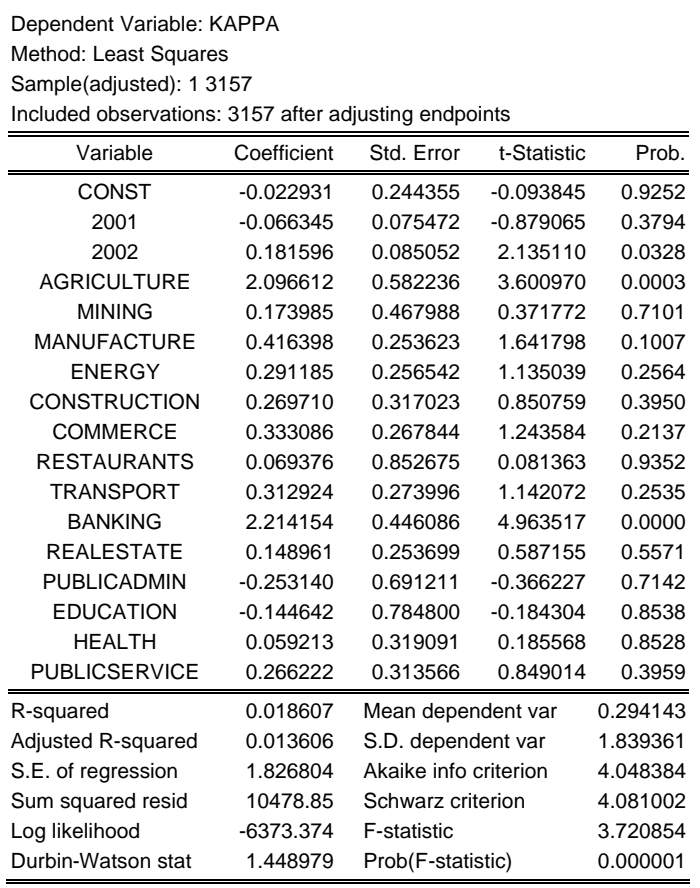

Table $6: \kappa$ and different branches

The high regression coefficients for these two branch dummies raise the question, if our 
estimated $\kappa>0$ can be explained simply by special provisions for agricultural firms and banks. In this case the constant should be near to zero if one adds just the variables "AGRICULTURE" and "BANKS". As table 7 shows, this is not the case.

\begin{tabular}{|c|c|c|c|c|}
\hline \multicolumn{5}{|c|}{$\begin{array}{l}\text { Dependent Variable: KAPPA } \\
\text { Method: Least Squares } \\
\text { Sample(adjusted): } 13157 \\
\text { Included observations: } 3157 \text { after adjusting endpoints }\end{array}$} \\
\hline Variable & Coefficient & Std. Error & t-Statistic & Prob. \\
\hline CONST & 0.247763 & 0.047420 & 5.224910 & 0.0000 \\
\hline 2001 & -0.056708 & 0.075070 & -0.755406 & 0.4501 \\
\hline 2002 & 0.196431 & 0.084501 & 2.324612 & 0.0202 \\
\hline AGRICULTURE & 1.817761 & 0.528533 & 3.439258 & 0.0006 \\
\hline BANKING & 1.938578 & 0.374438 & 5.177308 & 0.0000 \\
\hline R-squared & 0.014633 & \multicolumn{2}{|c|}{ Mean dependent var } & 0.294143 \\
\hline Adjusted R-squared & 0.013383 & \multicolumn{2}{|c|}{ S.D. dependent var } & 1.839361 \\
\hline S.E. of regression & 1.827011 & \multicolumn{2}{|c|}{ Akaike info criterion } & 4.044822 \\
\hline Sum squared resid & 10521.28 & \multicolumn{2}{|c|}{ Schwarz criterion } & 4.054416 \\
\hline Log likelihood & -6379.752 & \multicolumn{2}{|l|}{ F-statistic } & 11.70229 \\
\hline Durbin-Watson stat & 1.443698 & \multicolumn{2}{|c|}{ Prob(F-statistic) } & 0.000000 \\
\hline
\end{tabular}

Table 7: constant variable, agriculture and banking

\subsection{2 $\kappa$ and different organizational forms}

The most frequent organizational forms in our data sample are "GmbH" (1763 firms), "AG" (1229) and "GmbH\&Co KG" (69). Table 8 shows the regression results with respect to the three most frequent organizational forms in the data sample.

\begin{tabular}{|c|c|c|c|c|}
\hline \multicolumn{5}{|c|}{$\begin{array}{l}\text { Dependent Variable: KAPPA } \\
\text { Method: Least Squares } \\
\text { Sample(adjusted): } 13157 \\
\text { Included observations: } 3157 \text { after adjusting endpoints }\end{array}$} \\
\hline Variable & Coefficient & Std. Error & t-Statistic & Prob. \\
\hline CONST & -0.067945 & 0.190263 & -0.357112 & 0.7210 \\
\hline 2001 & -0.077926 & 0.075507 & -1.032047 & 0.3021 \\
\hline 2002 & 0.168421 & 0.085095 & 1.979214 & 0.0479 \\
\hline$A G$ & 0.504702 & 0.194397 & 2.596251 & 0.0095 \\
\hline GMBH & 0.262055 & 0.192200 & 1.363452 & 0.1728 \\
\hline GMBH\&COKG & 0.328384 & 0.289427 & 1.134598 & 0.2566 \\
\hline R-squared & 0.007711 & \multicolumn{2}{|c|}{ Mean dependent var } & 0.294143 \\
\hline Adjusted R-squared & 0.006137 & \multicolumn{2}{|c|}{ S.D. dependent var } & 1.839361 \\
\hline S.E. of regression & 1.833708 & \multicolumn{2}{|c|}{ Akaike info criterion } & 4.052456 \\
\hline Sum squared resid & 10595.19 & \multicolumn{2}{|c|}{ Schwarz criterion } & 4.063969 \\
\hline Log likelihood & -6390.802 & \multicolumn{2}{|l|}{ F-statistic } & 4.897289 \\
\hline Durbin-Watson stat & 1.435799 & \multicolumn{2}{|c|}{ Prob(F-statistic) } & 0.000182 \\
\hline
\end{tabular}

Table 8: $\kappa$ and different organizational forms

The AG-dummy (for "Aktiengesellschaft") is highly significant and suggests that $\kappa$ is bigger for AGs.

\subsection{3 $\kappa$ and the balance sheet structure}

Finally we look at general characteristics of the balance structure. Table 9 presents the regression results with respect to the size of the capital stock (CAP_SIZE), the leverage, the 
ratio of tangible goods relative to the total capital and a dummy for the use of loss carry forwards ${ }^{9}$.

\begin{tabular}{|c|c|c|c|c|}
\hline \multicolumn{5}{|c|}{$\begin{array}{l}\text { Dependent Variable: KAPPA } \\
\text { Method: Least Squares } \\
\text { Sample(adjusted): } 13157 \\
\text { Included observations: } 3157 \text { after adjusting endpoints }\end{array}$} \\
\hline Variable & Coefficient & Std. Error & t-Statistic & Prob. \\
\hline CONST & 0.803359 & 0.085490 & 9.397163 & 0.0000 \\
\hline 2001 & -0.065468 & 0.074722 & -0.876143 & 0.3810 \\
\hline 2002 & 0.194011 & 0.084138 & 2.305873 & 0.0212 \\
\hline CAP_SIZE & 4.24E-09 & 8.21E-09 & 0.516537 & 0.6055 \\
\hline LEVERAGE & -0.479279 & 0.142401 & -3.365688 & 0.0008 \\
\hline TANGIBLE & -0.804076 & 0.110450 & -7.280029 & 0.0000 \\
\hline LOSSCARRYFOR & 0.150676 & 0.156839 & 0.960702 & 0.3368 \\
\hline R-squared & 0.026275 & \multicolumn{2}{|c|}{ "Mean dependent var } & 0.294143 \\
\hline Adjusted R-squared & 0.024420 & \multicolumn{2}{|c|}{ S.D. dependent var } & 1.839361 \\
\hline S.E. of regression & 1.816763 & \multicolumn{2}{|c|}{ Akaike info criterion } & 4.034205 \\
\hline Sum squared resid & 10396.98 & \multicolumn{2}{|c|}{ Schwarz criterion } & 4.047636 \\
\hline Log likelihood & -6360.993 & \multicolumn{2}{|c|}{ F-statistic } & 14.16633 \\
\hline Durbin-Watson stat & 1.468853 & \multicolumn{2}{|c|}{ Prob(F-statistic) } & 0.000000 \\
\hline
\end{tabular}

Table 9: $\kappa$ and the balance structure

Only the leverage ratio and the tangible goods ratio are significantly different from zero. How can these results be interpreted? First, the size of the capital stock or the use of loss carry forward provisions seem to have no importance to explain the value of $\kappa$.

Second, the fact that $\kappa$ decreases when the debt ratio increases seems quite plausible. Since the cost of debt can be deducted from the tax base, a higher share of debt finance reduces the incentive to search for alternative tax shields.

Third, it seems difficult to explain, why a higher share of tangible assets reduces the use of special deductions. It is possible that immaterial capital goods can be faster depreciated than suggested in the KF assumptions. There may also be opportunities to depreciate losses related to financial assets which are not captured by standard KF assumptions.

\subsubsection{Multicollinearity?}

Our method to measure separately the impact of different factors raises the question of multicollinearity. Especially the clear results for the organizational forms and the balance structure might be linked somehow ${ }^{10}$. And, indeed, running regressions with the organizational form as dependent variable and the structural variables shows that these factors are not independent from each other.

The question remains which of the two types of variables is the one which drives the other. If we put the two types in one regression it turns out that the structural variables keep being highly significant whereas the organizational forms are not, as can be seen in table 10.

\footnotetext{
${ }^{9}$ Before using a quantitative variable we tested the dummy. Since it has no significant impact we abandoned the search in this direction.

${ }^{10}$ We tested for multicollinearity between the branch dummies and the structural variables, and the branches and organizational forms as well, but there are only weak linkages.
} 


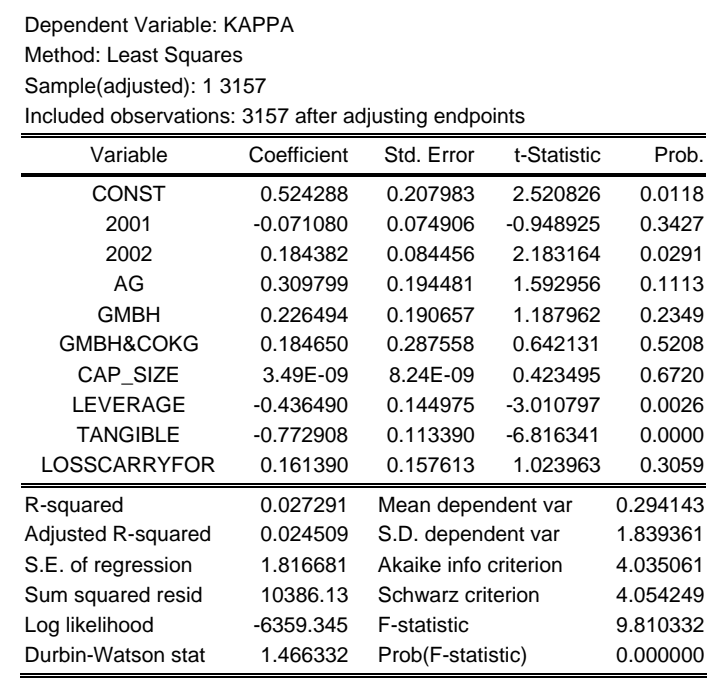

Table 10: $\kappa$, organizational form and balance structure

This could be a hint that AGs do not have higher $\kappa$ because of their organizational form but due to their specific balance sheet structure.

\section{Conclusions}

In this paper, we have developed a method of correcting conventional forward looking measures of effective taxation for real world complexities. Thus, our method offers an empirical test for the validity of assumptions on depreciation deductions used for the construction of forward looking measures. On the basis of our estimates of the "true" use of depreciation deductions, we are able to compute "adjusted effective tax rates" for marginal investment decisions.

We have applied our method to the DAFNE dataset of German firms. It turns out that depreciation deductions used by the median (average) firm exceed the depreciation deductions asumed by $\mathrm{KF}$ measures by $7 \%(30 \%)$. If these estimates are correct, the KF concept systematically overestimates the effective tax burden on investment. To demonstrate the bias caused by the misestimation of depreciation deductions we have computed the effective marginal tax rates with different assumptions on the use of special deductions. It turns out that even small errors in the specification of the deductions pattern lead to considerable variations in the measures of effective taxation.

The regression analysis shows that $\kappa$ rises with an increasing share of equity finance and an decreasing share of tangible assets. The banking and the agricultural sectors depreciate more than other branches.

These results suggest that the approach developed here might be a first step towards reconciling the different results of studies based on forward and backward looking indicators. The fact that backward looking indicators, in particular macro indicators, often find a lower 
effective tax burden on investment may partly be due to the failure of forward looking concepts to take into account all possibilities of firms to use deduction possibilities offered by the tax law.

\section{References}

Devereux, M. P. \& Griffith, R. (1998). Taxes and the location of production: Evidence from a panel of US multinationals, Journal of Public Economics (68) 3: 335-367.

Gordon, R., Kalambokidis, L. \& Slemrod, J. (2003). A new summary measure of the effective tax rate on investment, NBER Working Paper No. 9535.

Jacobs, O. H. \& Spengel, C. (1996). European Tax Analyzer, Nomos, Baden-Baden.

King, M. A. \& Fullerton, D. (1984). The Taxation of Income from Capital, University of Chicago Press, Chicago und London.

Sachverständigenrat (2001). Für Stetigkeit - Gegen Aktionismus, Jahresgutachten 2001/2002, Metzler-Poeschel, Stuttgart.

Spengel, C. (2001). Der Steuerstandort Deutschland im Internationalen Vergleich, Eine Analyse Vor Dem Hintergrund Des Steuersenkungsgesetzes 2001, Expertise Für Den Sachverständigenrat Zur Begutachtung der Gesamtwirtschaftlichen Entwicklung, Universität Mannheim. 


\section{CESifo Working Paper Series}

(for full list see www.cesifo.de)

1281 Ayal Kimhi, Growth, Inequality and Labor Markets in LDCs: A Survey, September 2004

1282 Robert Dur and Amihai Glazer, Optimal Incentive Contracts for a Worker who Envies his Boss, September 2004

1283 Klaus Abberger, Nonparametric Regression and the Detection of Turning Points in the Ifo Business Climate, September 2004

1284 Werner Güth and Rupert Sausgruber, Tax Morale and Optimal Taxation, September 2004

1285 Luis H. R. Alvarez and Erkki Koskela, Does Risk Aversion Accelerate Optimal Forest Rotation under Uncertainty?, September 2004

1286 Giorgio Brunello and Maria De Paola, Market Failures and the Under-Provision of Training, September 2004

1287 Sanjeev Goyal, Marco van der Leij and José Luis Moraga-González, Economics: An Emerging Small World?, September 2004

1288 Sandro Maffei, Nikolai Raabe and Heinrich W. Ursprung, Political Repression and Child Labor: Theory and Empirical Evidence, September 2004

1289 Georg Götz and Klaus Gugler, Market Concentration and Product Variety under Spatial Competition: Evidence from Retail Gasoline, September 2004

1290 Jonathan Temple and Ludger Wößmann, Dualism and Cross-Country Growth Regressions, September 2004

1291 Ravi Kanbur, Jukka Pirttilä and Matti Tuomala, Non-Welfarist Optimal Taxation and Behavioral Public Economics, October 2004

1292 Maarten C. W. Janssen, José Luis Moraga-González and Matthijs R. Wildenbeest, Consumer Search and Oligopolistic Pricing: An Empirical Investigation, October 2004

1293 Kira Börner and Christa Hainz, The Political Economy of Corruption and the Role of Financial Institutions, October 2004

1294 Christoph A. Schaltegger and Lars P. Feld, Do Large Cabinets Favor Large Governments? Evidence from Swiss Sub-Federal Jurisdictions, October 2004

1295 Marc-Andreas Mündler, The Existence of Informationally Efficient Markets When Individuals Are Rational, October 2004 
1296 Hendrik Jürges, Wolfram F. Richter and Kerstin Schneider, Teacher Quality and Incentives: Theoretical and Empirical Effects of Standards on Teacher Quality, October 2004

1297 David S. Evans and Michael Salinger, An Empirical Analysis of Bundling and Tying: Over-the-Counter Pain Relief and Cold Medicines, October 2004

1298 Gershon Ben-Shakhar, Gary Bornstein, Astrid Hopfensitz and Frans van Winden, Reciprocity and Emotions: Arousal, Self-Reports, and Expectations, October 2004

1299 B. Zorina Khan and Kenneth L. Sokoloff, Institutions and Technological Innovation During Early Economic Growth: Evidence from the Great Inventors of the United States, 1790 - 1930, October 2004

1300 Piero Gottardi and Roberto Serrano, Market Power and Information Revelation in Dynamic Trading, October 2004

1301 Alan V. Deardorff, Who Makes the Rules of Globalization?, October 2004

1302 Sheilagh Ogilvie, The Use and Abuse of Trust: Social Capital and its Deployment by Early Modern Guilds, October 2004

1303 Mario Jametti and Thomas von Ungern-Sternberg, Disaster Insurance or a Disastrous Insurance - Natural Disaster Insurance in France, October 2004

1304 Pieter A. Gautier and José Luis Moraga-González, Strategic Wage Setting and Coordination Frictions with Multiple Applications, October 2004

1305 Julia Darby, Anton Muscatelli and Graeme Roy, Fiscal Federalism, Fiscal Consolidations and Cuts in Central Government Grants: Evidence from an Event Study, October 2004

1306 Michael Waldman, Antitrust Perspectives for Durable-Goods Markets, October 2004

1307 Josef Honerkamp, Stefan Moog and Bernd Raffelhüschen, Earlier or Later: A General Equilibrium Analysis of Bringing Forward an Already Announced Tax Reform, October 2004

1308 M. Hashem Pesaran, A Pair-Wise Approach to Testing for Output and Growth Convergence, October 2004

1309 John Bishop and Ferran Mane, Educational Reform and Disadvantaged Students: Are They Better Off or Worse Off?, October 2004

1310 Alfredo Schclarek, Consumption and Keynesian Fiscal Policy, October 2004

1311 Wolfram F. Richter, Efficiency Effects of Tax Deductions for Work-Related Expenses, October 2004 
1312 Franco Mariuzzo, Patrick Paul Walsh and Ciara Whelan, EU Merger Control in Differentiated Product Industries, October 2004

1313 Kurt Schmidheiny, Income Segregation and Local Progressive Taxation: Empirical Evidence from Switzerland, October 2004

1314 David S. Evans, Andrei Hagiu and Richard Schmalensee, A Survey of the Economic Role of Software Platforms in Computer-Based Industries, October 2004

1315 Frank Riedel and Elmar Wolfstetter, Immediate Demand Reduction in Simultaneous Ascending Bid Auctions, October 2004

1316 Patricia Crifo and Jean-Louis Rullière, Incentives and Anonymity Principle: Crowding Out Toward Users, October 2004

1317 Attila Ambrus and Rossella Argenziano, Network Markets and Consumers Coordination, October 2004

1318 Margarita Katsimi and Thomas Moutos, Monopoly, Inequality and Redistribution Via the Public Provision of Private Goods, October 2004

1319 Jens Josephson and Karl Wärneryd, Long-Run Selection and the Work Ethic, October 2004

1320 Jan K. Brueckner and Oleg Smirnov, Workings of the Melting Pot: Social Networks and the Evolution of Population Attributes, October 2004

1321 Thomas Fuchs and Ludger Wößmann, Computers and Student Learning: Bivariate and Multivariate Evidence on the Availability and Use of Computers at Home and at School, November 2004

1322 Alberto Bisin, Piero Gottardi and Adriano A. Rampini, Managerial Hedging and Portfolio Monitoring, November 2004

1323 Cecilia García-Peñalosa and Jean-François Wen, Redistribution and Occupational Choice in a Schumpeterian Growth Model, November 2004

1324 William Martin and Robert Rowthorn, Will Stability Last?, November 2004

1325 Jianpei Li and Elmar Wolfstetter, Partnership Dissolution, Complementarity, and Investment Incentives, November 2004

1326 Hans Fehr, Sabine Jokisch and Laurence J. Kotlikoff, Fertility, Mortality, and the Developed World's Demographic Transition, November 2004

1327 Adam Elbourne and Jakob de Haan, Asymmetric Monetary Transmission in EMU: The Robustness of VAR Conclusions and Cecchetti's Legal Family Theory, November 2004

1328 Karel-Jan Alsem, Steven Brakman, Lex Hoogduin and Gerard Kuper, The Impact of Newspapers on Consumer Confidence: Does Spin Bias Exist?, November 2004 
1329 Chiona Balfoussia and Mike Wickens, Macroeconomic Sources of Risk in the Term Structure, November 2004

1330 Ludger Wößmann, The Effect Heterogeneity of Central Exams: Evidence from TIMSS, TIMSS-Repeat and PISA, November 2004

1331 M. Hashem Pesaran, Estimation and Inference in Large Heterogeneous Panels with a Multifactor Error Structure, November 2004

1332 Maarten C. W. Janssen, José Luis Moraga-González and Matthijs R. Wildenbeest, A Note on Costly Sequential Search and Oligopoly Pricing, November 2004

1333 Martin Peitz and Patrick Waelbroeck, An Economist's Guide to Digital Music, November 2004

1334 Biswa N. Bhattacharyay and Prabir De, Promotion of Trade, Investment and Infrastructure Development between China and India: The Case of Southwest China and East and Northeast India, November 2004

1335 Lutz Hendricks, Why Does Educational Attainment Differ Across U.S. States?, November 2004

1336 Jay Pil Choi, Antitrust Analysis of Tying Arrangements, November 2004

1337 Rafael Lalive, Jan C. van Ours and Josef Zweimueller, How Changes in Financial Incentives Affect the Duration of Unemployment, November 2004

1338 Robert Woods, Fiscal Stabilisation and EMU, November 2004

1339 Rainald Borck and Matthias Wrede, Political Economy of Commuting Subsidies, November 2004

1340 Marcel Gérard, Combining Dutch Presumptive Capital Income Tax and US Qualified Intermediaries to Set Forth a New System of International Savings Taxation, November 2004

1341 Bruno S. Frey, Simon Luechinger and Alois Stutzer, Calculating Tragedy: Assessing the Costs of Terrorism, November 2004

1342 Johannes Becker and Clemens Fuest, A Backward Looking Measure of the Effective Marginal Tax Burden on Investment, November 2004 